\title{
Coffee pulp supplementation prior to breeding improves oxidative status without affecting fertility of primiparous ewes
}

\author{
La suplementación con pulpa de café antes de la monta mejora el estado oxidativo sin afectar la fertilidad \\ de ovejas primiparas \\ A suplementação de polpa de café antes da reprodução melhora o estado oxidativo sem afetar a \\ fertilidade de ovelhas primíparas
}

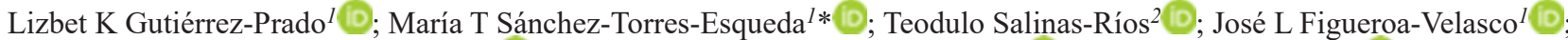

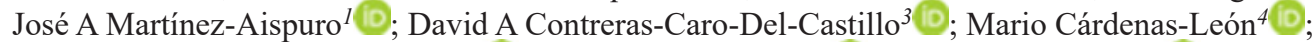

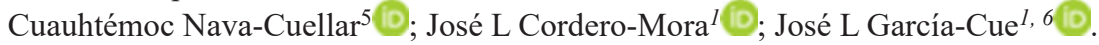

\footnotetext{
${ }^{1}$ Programa de Ganadería Colegio de Postgraduados, Campus Montecillo, Texcoco, Estado de México, México.

${ }^{2}$ Facultad de Medicina Veterinaria y Zootecnia, Universidad Autónoma Benito Juárez de Oaxaca, Oaxaca, México.

${ }^{3}$ Departamento de Medicina Veterinaria y Zootecnia de Rumiantes, FMVZ-UNAM. Ciudad de México, México.

${ }^{4}$ Laboratorio de Biología de la Reproducción, Instituto Nacional de Ciencias Médicas y Nutrición, Tlalpan, Ciudad de México, México.

${ }^{5}$ Departamento de Bioquímica, FMV-UNAM. Ciudad de México, México.

${ }^{6}$ Programa de Socioeconomía Estadística e Informática, Colegio de Postgraduados, Campus Montecillo, Texcoco, Estado de México.
}

Received: June 28, 2017; accepted: April 12, 2019

To cite this article:

Gutiérrez-Prado LK, Sánchez-Torres-Esqueda MT, Salina-Ríos T, Figueroa-Velasco JL, Martínez-Aispuro JA, ContrerasCaro del Castillo DA, Cárdenas-León M, Nava-Cuellar C, Cordero-Mora JL, García-Cue JL. Coffee pulp supplementation prior to breeding improves oxidative status without affecting fertility of primiparous ewes. Rev Colomb Cienc Pecu 2019; 32(4): 261-273. DOI: https://doi.org/10.17533/udea.rccp.v32n4a02

\footnotetext{
(cc) BY-NC-SA This work is licensed under a Creative Commons Attribution-NonCommercial-ShareAlike 4.0 International License.
} 


\begin{abstract}
Background: Coffee pulp has a high content of antioxidants capable of modifying the oxidative status in small ruminants. However, high amounts for a prolonged time can reduce fertility. Objective: To determine the effect of two inclusion levels of coffee pulp during estrous synchronization on reproductive variables and oxidative status of primiparous ewes. Methods: Sixty Suffolk x Dorset primiparous ewes were distributed into three treatments in a completely randomized design; T0: $(\mathrm{n}=20) 1.5 \mathrm{~kg}$ balanced diet, T1: $(\mathrm{n}=20) 1.5 \mathrm{~kg}$ balanced diet and 5\% coffee pulp, T2: $(\mathrm{n}=20) 1.5 \mathrm{~kg}$ balanced diet and $10 \%$ coffee pulp. Supplementation was given for 16 days before estrus synchronization and until the beginning of the breeding season. A progestogen (CIDR ${ }^{\circledR}$ ) was inserted for 11 days and a dose of PGF2 $\alpha$ was applied two days prior to its withdrawal. Estrus detection started 12 hours after CIDR withdrawal. Blood samples were obtained during the supplementation period to measure oxidative status, antioxidant capacity, glucose and insulin, and up to 9 days after breeding to determine progesterone concentration. Pregnancy diagnosis was performed at 30 and 60 days post-breeding. An analysis of repeated measures of mixed effects and frequency analysis were carried out. Results: Inclusion of coffee pulp for a short period prior to breeding did not affect reproductive parameters, nor progesterone, glucose or insulin concentrations ( $p>0.05$ ); however, antioxidant capacity increased, while lipid oxidation showed an opposite trend $(\mathrm{p}<0.05)$. Conclusion: Inclusion of up to $10 \%$ coffee pulp in the diet of ewe lambs for 16 days prior to breeding improves oxidative status without causing adverse effects on pregnancy, estrus or prolificacy.
\end{abstract}

Keywords: antioxidant capacity; caffeine; coffee pulp; estrus synchronization; ewes; fertility lipoperoxidation; oxidative stress; reproductive parameters; sheep.

\title{
Resumen
}

Antecedentes: La pulpa de café tiene un alto contenido de antioxidantes capaces de modificar el estado oxidativo en pequeños rumiantes. Sin embargo, a dosis elevadas y por un tiempo prolongado puede reducir la fertilidad. Objetivo: Determinar el efecto de dos niveles de inclusión de pulpa de café durante la sincronización del estro en variables reproductivas y el estado oxidativo de ovejas primerizas. Métodos: Se utilizaron 60 ovejas primalas Suffolk x Dorset fueron distribuidas en tres tratamientos en un diseño completamente al azar; T0: $(\mathrm{n}=20)$ con 1,5 $\mathrm{kg}$ de dieta integral, $\mathrm{T} 1:(\mathrm{n}=20) \mathrm{con} 1,5 \mathrm{~kg}$ de dieta integral y $5 \%$ de pulpa de café, T2: $(\mathrm{n}=20)$ con $1,5 \mathrm{~kg}$ de dieta integral y $10 \%$ de pulpa de café. La suplementación se realizó por 16 días, previo a la sincronización del estro y hasta el empadre. El progestágeno (CIDR $®)$ se insertó en las ovejas por 11 días y se aplicó una dosis de PGF2 $\alpha$ dos días antes de su retiro. La detección de estro comenzó a las 12 horas post-retiro del CIDR ${ }^{\circledR}$. Se obtuvieron muestras sanguíneas durante el periodo de suplementación para medir estado oxidativo, capacidad antioxidante, glucosa e insulina, y hasta 9 días posteriores al empadre para determinar las concentraciones de progesterona. El diagnóstico de gestación se realizó a los 30 y 60 días post-monta. Se realizaron análisis de medidas repetidas utilizando un modelo de efectos mixtos, además de análisis de frecuencias. Resultados: La inclusión de pulpa por un periodo corto previo al empadre no afectó los parámetros reproductivos ni las concentraciones de progesterona, glucosa o insulina ( $p>0,05)$; sin embargo, la capacidad antioxidante se incrementó, mientras que la oxidación lipídica siguió una tendencia inversa $(\mathrm{p}<0,05)$. Conclusión: La inclusión hasta de $10 \%$ de pulpa de café en la dieta de ovejas por 16 días previo al empadre mejora el estado oxidativo sin ocasionar efectos adversos en el porcentaje de preñez, estro o prolificidad.

Palabras claves: cafeina; capacidad antioxidante; estrés oxidativo; fertilidad; lipoperoxidación; ovejas; ovinos; parámetros reproductivos; pulpa de café; sincronización del estro.

\section{Resumo}

Antecedentes: A polpa de café tem alto conteúdo de antioxidantes capazes de modificar o estado oxidativo em pequenos ruminantes; no entanto, em doses elevadas e por um tempo prolongado reduz a fertilidade. Objetivo: Determinar o efeito de diferentes níveis de inclusão de polpa de café durante a sincronização do estro em diferentes variáveis reprodutivas e estado oxidativo das ovelhas primíparas. Métodos: Sessenta ovelhas primíparas dos cruzamentos Suffolk x Dorset foram distribuídas em três tratamentos em um design completamente aleatório; T0: $(\mathrm{n}=20)$ com 1,5 $\mathrm{kg}$ de dieta completa, $\mathrm{T} 1:(\mathrm{n}=20) \mathrm{com} 1,5 \mathrm{~kg}$ de dieta completa contendo $5 \%$ de polpa de café, T2: $(\mathrm{n}=20)$ com $1,5 \mathrm{~kg}$ de dieta completa contendo $10 \%$ de polpa de café. A suplementação realizou-se por 16 dias, antes do início da sincronização de estros e até o momento do acasalamento. O progestogênio (CIDR) foi inserido nas ovelhas durante 11 dias e uma dose de PGF2 $\alpha$ foi aplicada dois dias antes da sua retirada. Doze horas após a retirada do CIDR iniciou-se a detecção de estros. Foram obtidas amostras de sangue durante o período de 
suplementação, para medição do estado oxidativo, capacidade antioxidante, glicose e insulina e até 9 dias posteriores ao início da estação de monta para determinar as concentrações de progesterona. O diagnostico de gestação realizou-se aos 30 e 60 dias post-monta. Uma análise de medidas repetidas de efeitos mistos e análise de freqüência foi realizada. Resultados: A inclusão de polpa por um período curto antes da estação de monta não afetou os parâmetros reprodutivos nem as concentrações de progesterona, glicose e insulina ( $\mathrm{p}>0,05)$; porém, a capacidade antioxidante nas ovelhas foi aumentada, enquanto a oxidação lipídica seguiu uma tendência inversa $(\mathrm{p}<0,05)$. Conclusão: Inclusão de polpa de café na dieta de ovelha até $10 \%$ durante 16 dias antes do acasalamento melhora o estado oxidativo, sem causar efeitos adversos na porcentagem de gravidez, estro e prolificidade.

Palavras-chave: cafeina; capacidade antioxidante; estresse oxidativo; fertilidade; lipoperoxidação; ovelhas; parâmetros reprodutivos; polpa de café; sincronização do estro.

\section{Introduction}

Susceptibility to oxidation increases during gestation and around birth (Castillo et al., 2005; Berchieri-Ronchi et al., 2011), and lipid oxidation can affect embryonic preimplantation (Guerin et al., 2001). As a result, multiple physiological processes such as oocyte maturation, fertilization, embryo development, and pregnancy can be affected (Agarwal et al., 2005). Several researchers have studied antioxidant supplementation during these stages in order to increase antioxidant capacity (Casamassima et al., 2012). A study by SalinasRios et al. (2016) found that antioxidant capacity decreases at the beginning of gestation. Thus, demand for antioxidants could increase prior to pregnancy and in early gestation.

Around 10 million tons of coffee residues are generated in the main producing countries (Echeverria and Nuti, 2017). Several studies have been conducted with the aim of using this residue in animal feeding (Lima de Souza et al., 2010; Salinas-Rios et al., 2015). In dairy cows, coffee pulp can be included up to $20 \%$ of the diet without affecting dry matter intake, milk production and composition, or body weight (Pedraza-Beltrán et al., 2012). However, little is known about the use of coffee pulp in reproduction. Considering its antioxidant compounds (Salinas et al., 2014), coffee residues have been tested prior to mating and during early gestation in sheep, finding that supplementation with $450 \mathrm{~g}$ concentrate with $25 \%$ coffee pulp decreased gestation. Additionally, no more losses are observed when supplementation is suspended. Coffee pulp contains $0.57 \%$ caffeine (Salinas et al., 2014) which could cause reproductive problems, since studies in women have reported that high caffeine intake reduces fertility (Fumihiro et al., 2005). However, Nawrot et al. (2003) reported that this effect on fertility is reduced for intakes lower than $300 \mathrm{mg} /$ day. Caffeine exerts its effects only at the time it is delivered, and these effects disappear within 2 to 12 hours after consumption (Benowitz et al., 1990; Daly et al., 1993), so we hypothesized that reducing the amount of coffee pulp and suspending supplementation prior to mating could avoid embryonic losses.

Therefore, the aim of this work was to determine the oxidative status and reproductive efficiency of primiparous ewes supplemented with two levels of coffee pulp during estrus synchronization.

\section{Materials and methods}

\section{Ethical considerations}

The study was conducted at the experimental farm of Colegio de Postgraduados, Campus Montecillo, Mexico, under the rules of animal welfare, biosecurity and ethics of this institution, in compliance with the official Mexican norm NOM-062-ZOO-1999 (SAGARPA, 2001). 


\section{Experimental design and feeding}

Sixty Dorset $\mathrm{x}$ Suffolk ewe lambs were used, with $48.66 \pm 5.18 \mathrm{~kg}$ average weight and a body condition of 3 on a 1 to 5 scale. Ewes were distributed in a completely randomized design with three treatments of 20 animals each. A balanced diet according to the NRC (1985) requirements was offered (Table 1).
Dietary treatments were: $\mathrm{T} 0=$ without coffee pulp, $\mathrm{T} 1=$ with $5 \%$ coffee pulp, and $\mathrm{T} 2=$ with $10 \%$ coffee pulp.In order for all sheep to consume the same amount of feed, the average consumption was estimated for three days, which was $1.5 \mathrm{~kg}$ per animal. This amount was provided in two meals (8:00 am and 4:00 pm) for 16 days, starting two days before inserting the CIDR and until the moment of service.

Table 1. Composition of the diets fed to sheep during synchronization.

\begin{tabular}{llll}
\hline INGREDIENT & T0 & T1 & T2 \\
\hline Corn grain \% & 24.27 & 24.27 & 24.27 \\
Soybean meal \% & 9.04 & 9.04 & 9.04 \\
Molasses \% & 5.27 & 5.27 & 5.27 \\
Mineral salt * \% & 0.95 & 0.95 & 0.95 \\
Coffee pulp \% & 0.0 & 5.00 & 10.00 \\
Oat hay \% & 60.47 & 55.47 & 50.47 \\
Total & 100 & 100 & 100 \\
COMPOSITION & & & \\
\hline DM \% & 95.28 & 95.20 & 95.15 \\
CP \% & 12.01 & 12.09 & 12.13 \\
Mcal EM/kg & 2.4 & 2.4 & 2.4 \\
CF \% & 22.92 & 22.0 & 22.1 \\
Ash & 7.66 & 7.44 & 7.34 \\
\hline
\end{tabular}

* Phosphorus 17.5\%; Sodium 12.9\%; Calcium 5.6\%; Magnesium 3.4\%. T0 = treatment without coffee pulp; $\mathrm{T} 1=$ treatment with $5 \%$ coffee pulp; and $\mathrm{T} 2=$ treatment with $10 \%$ of coffee pulp in the diet. $\mathrm{DM}=$ dry matter; $\mathrm{CP}=$ crude protein; and $\mathrm{CF}=$ crude fiber.

A sample of extract was obtained from the diet to determine antioxidant capacity, following the methodology described by Restrepo-Sánchez et al. (2009), making small modifications and using the FRAP (ferric reducing ability of plasma) from Benzie and Strain (1999).

\section{Estrus synchronization}

Pre-synchronization was carried out with two doses of $125 \mu \mathrm{g}$ PGF2 $\alpha$ (cloprostenol) at an interval of eight days. Six days after the second application, an intravaginal device impregnated with $0.3 \mathrm{~g}$ progesterone (CIDR $®)$ was inserted and kept for 11 days. Twelve hours after CIDR withdrawal, estrus was detected with males fitted with aprons at $6 \mathrm{~h}$ 


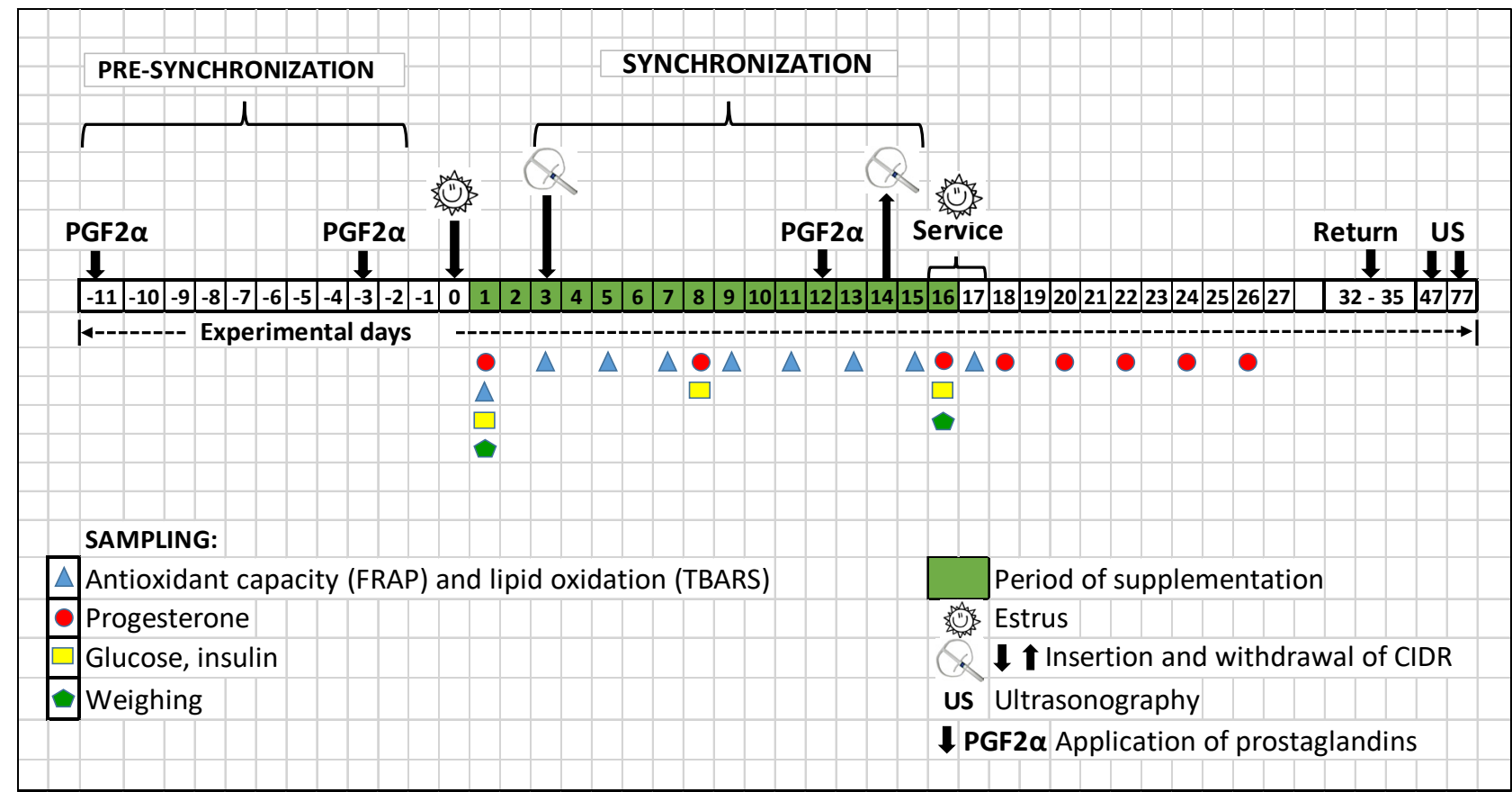

Figure 1. Estrus synchronization protocol and sampling to measure oxidative status, progesterone, glucose and insulin in sheep supplemented with coffee pulp. CIDR: vaginal progesterone-releasing device; PGF2 $\alpha$ : prostaglandins; TBARS: reactive substances to the thiobarbituric acid; FRAP: antioxidant power of ferric reduction.

\section{Oxidative state}

To determine antioxidant capacity and lipid oxidation, nine samples were collected every third day, starting two days before the supplementation and until breeding (Figure 1). Blood samples were obtained from the jugular vein from fasted ewes at $8: 00 \mathrm{~h}$ in $5 \mathrm{ml}$ vacutainer tubes with EDTA (ethylenediaminetetraacetic acid). Samples were centrifuged at 2,500 rpm for 20 minutes at $-4^{\circ} \mathrm{C}$ (SIGMA 2-16 PK SIGMA Laborzentrifugen Gmbh, Osterode am Harz, Germany). Plasma was aliquoted in $1.5 \mathrm{ml}$ Eppendorf tubes and stored at $-40^{\circ} \mathrm{C}$ until further analysis. For antioxidant capacity determination, FRAP from Benzie and Strain (1999) was used, and for lipid oxidation the technique by Ohkawa (1979) was employed.

\section{Progesterone (P4), glucose and insulin}

Eight samples were collected to determine $\mathrm{P} 4$, and three for glucose and insulin at the beginning, middle and at the end of the dietary supplementation (Figure 1). Progesterone determination was done by an immunoenzymatic assay (Immunometrics, UK Ltd, 280 Muster Road, London SW6 6BQ) with 0.13 ng mL-1 analytical sensitivity, and intra- and inter-assay coefficient of variations of 9.59 and $13.7 \%$, respectively. Plasma insulin analysis was performed by Radioimmunoassay (RIA) with $4.09 \mathrm{ng} \mathrm{mL}$ sensitivity, and intra- and inter-assay coefficients of variations of 1.44 and $0.25 \%$, respectively. Glucose determinations were performed by the enzymatic method based on glucose oxidase (Pointe Scientific, Inc, USA.).

\section{Statistical analysis}

The number of offspring and gestation rate (\%) were analyzed under the procedure PROC FREQ with the chi-square test. For percentage of births, birth weight, onset and duration of estrus a Tukey mean comparison tests were applied using PROC GLM procedure of SAS ${ }^{\circledR}$ software, Version 9 (SAS Institute Inc, Cary, NC, USA) (2002). 
Antioxidant capacity, lipid oxidation, progesterone, glucose and insulin variables were tested for normality and homogeneity of variances and analyzed under the test of repeated measurements over time using PROC MIXED. The statistical model was:

$$
\mathrm{Y}_{i j k}=\mu+\mathrm{T}_{i}+\mathrm{M}_{j}+\mathrm{T}_{i} \mathrm{M}_{j}+\mathrm{Ak}_{(i)}+\mathrm{E}_{i j k} .
$$

Where:

$\mathrm{Y}_{i j k}=$ is the response of the $\mathrm{i}$-th treatment in the $\mathrm{j}$-th sampling of the $\mathrm{k}$-th repetition, $\mu=$ is the general mean, $\mathrm{Ti}=$ is the effect of $\mathrm{i}$-th treatment, $\mathrm{M}_{j}=$ is the effect of $\mathrm{j}$-th sampling, $\mathrm{T}_{i} \mathrm{M}_{j}=$ is the effect of $\mathrm{i}$-th treatment in $\mathrm{j}$-th sampling, Ak (i)= Effect of the $\mathrm{i}$-th treatment nested on the $\mathrm{k}$-th animal, $\mathrm{E}_{i j k}=$ Experimental error. A Tukey test was performed for the variables that showed a significant difference $(\mathrm{p}<0.05)$.

\section{Results}

\section{Antioxidant effect of diets}

Antioxidant effect of diets fed to the animals increased when the level of inclusion of coffee pulp was higher. $\mathrm{T} 1, \mathrm{~T} 2$, and $\mathrm{T} 3$ resulted in 45.18, 51.55, and $137.02 \mu \mathrm{mol}$ trolox/g DM, respectively (Table 2 ).

Table 2. Antioxidant capacity of diets fed to ewes during estrus synchronization.

\begin{tabular}{|c|c|c|c|}
\hline VARIABLE & T0 & T1 & $\mathbf{T} 2$ \\
\hline $\begin{array}{c}\text { FRAP } \\
(\mu \mathrm{mol} \text { trolox/g MS })\end{array}$ & 45.18 & 51.55 & 137.02 \\
\hline
\end{tabular}

Table 3. Reproductive variables of synchronized ewes supplemented with coffee pulp.

\begin{tabular}{llll}
\hline & T0 & T1 & T2 \\
\hline Estrus (\%) & 100 & 100 & 100 \\
& & & 34.8 \\
Estrus onset (hours) & 32.7 & 34.8 & 27.0 \\
Estrus duration (hours) & 28.2 & 27.6 & $(19 / 20) 95$ \\
30 days gestation (\%) & $(18 / 20) 90$ & $(18 / 20) 90$ & $(19 / 20) 95$ \\
60 days gestation (\%) & $(18 / 20) 90$ & $(18 / 20) 90$ & $(19 / 20) 95$ \\
Births (\%) & $(18 / 20) 90$ & $(18 / 20) 90$ & $1.25 \pm 0.44$ \\
Prolificacy & $1.38 \pm 0.50$ & $1.23 \pm 0.43$ & $4.38 \pm 0.71$ \\
Litter weight at & $4.20 \pm 0.81$ & $4.46 \pm 0.94$ & \\
birth $(\mathrm{kg})$ & & & \\
\hline
\end{tabular}

$\mathrm{T} 0=$ treatment without coffee pulp; $\mathrm{T} 1=$ treatment with $5 \%$ and $\mathrm{T} 2=$ treatment with $10 \%$ inclusion of coffee pulp in the diet. No statistical differences were found $(\mathrm{p}>0.05)$.

\section{Reproductive variables}

After CIDR withdrawal, $100 \%$ of the ewes presented estrus. Coffee pulp inclusion for the 5 and $10 \%$ diets did not modify the onset or duration of estrus, neither the gestation percentage at 30 and 60 days, nor the number of offspring or birth weight $(\mathrm{p}>0.05)$ (Table 3$)$. 


\section{Antioxidant capacity in blood}

The antioxidant capacity of blood plasma increased $(p<0.05)$ as the percentage of coffee pulp inclusion increased, being greater in ewes fed $10 \%$, followed by supplementation with $5 \%$, and, finally, the control treatment (Table 4).

Table 4. Antioxidant capacity and lipid oxidation in ewes fed different inclusion levels of coffee pulp during estrus synchronization.

\begin{tabular}{|c|c|c|c|c|}
\hline Treatment & $\begin{array}{c}\text { Trolox } \\
\left(\mathrm{nmol} \mathrm{ml}^{-1}\right)\end{array}$ & SEM & $\begin{array}{c}\text { MDA } \\
\left(\mathrm{nmol} \mathrm{ml}^{-1}\right)\end{array}$ & SEM \\
\hline T0 & $285.79^{c}$ & 0.03 & $5.99^{\mathrm{a}}$ & 0.05 \\
\hline $\mathrm{T} 1$ & $331.56^{\mathrm{b}}$ & 0.03 & $5.22^{\mathrm{ab}}$ & 0.05 \\
\hline $\mathrm{T} 2$ & $363.85^{\mathrm{a}}$ & 0.03 & $5.02^{\mathrm{b}}$ & 0.05 \\
\hline
\end{tabular}

Different superscript letters $(\mathrm{a}, \mathrm{b}, \mathrm{c})$ within the same column indicate statistically significant differences $(\mathrm{p}<0.05)$. T0 $=$ treatment without coffee pulp; $\mathrm{T} 1=$ treatment with $5 \%$; and $\mathrm{T} 2=$ treatment with $10 \%$ inclusion of coffee pulp in the diet. MDA: malondialdehyde; SEM: standard error of the mean.

During sampling, antioxidant capability decreased after CIDR withdrawal (Figure 2).

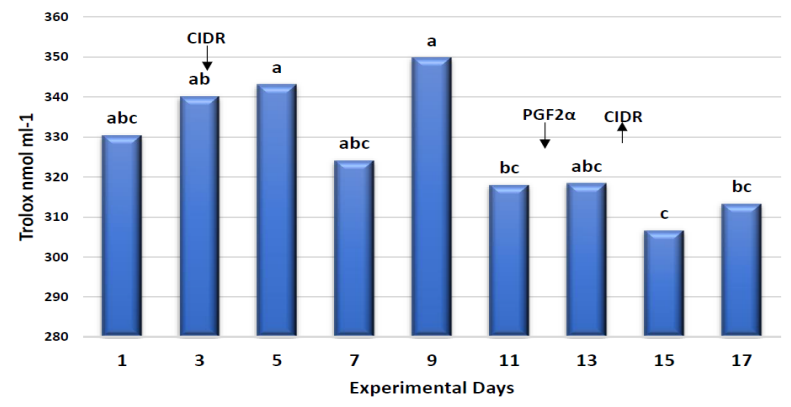

Figure 2. Antioxidant capacity in ewes during estrus synchronization with progestogen. CIDR: vaginal progesterone-releasing device; PGF2 $\alpha$ : F2 $\alpha$ prostaglandin; Trolox: trolox equivalent antioxidant capacity. Different letters $(a, b, c)$ indicate statistically significant differences between bars $(p<0.05)$.

\section{Lipid oxidation}

Inclusion of $10 \%$ coffee pulp in the diet reduced $(\mathrm{p}<0.05)$ lipid oxidation in plasma with respect to control ewes. There was no statistical difference $(p>0.05)$ between inclusion of 10 and 5\%; nevertheless, as coffee pulp inclusion increased lipid oxidation in the blood decreased (Table 4). Regarding the date of sampling, there was no clear effect of lipid oxidation through sampling. Lowest values $(p<0.05)$ were found between experimental days 9 to 15 (corresponding to 5 days before CIDR withdrawal and 5 days after) with respect to days 1, 5, 7 and 17 (Figure 3).

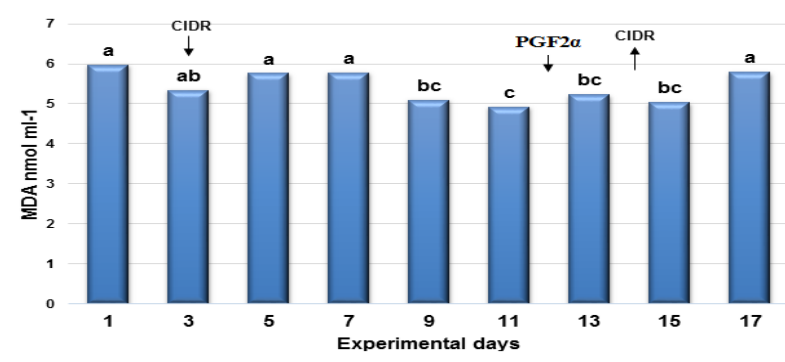

Figure 3. Lipid oxidation in ewes during estrus synchronization with progestogen. CIDR: vaginal progesterone-releasing device, PGF2 $\alpha$ :F2 $\alpha$-prostaglandin. MDA: malondialdehyde. Different letters $(a, b, c)$ indicate statistically significant differences between bars $(\mathrm{p}<0.05)$.

\section{Progesterone (P4)}

There were no statistical differences $(\mathrm{p}>0.05)$ 
in $\mathrm{P} 4$ concentration with the inclusion of 5 to $10 \%$ of coffee pulp during estrus synchronization. Regarding sampling date, a higher concentration of progesterone $(\mathrm{p}<0.05)$ was observed when ewes had the CIDR (experimental day 8), decreasing after withdrawal, followed by a gradual increase from experimental day 18, corresponding to one day after mating (Figure 4 ), and maintaining a normal secretion profile.

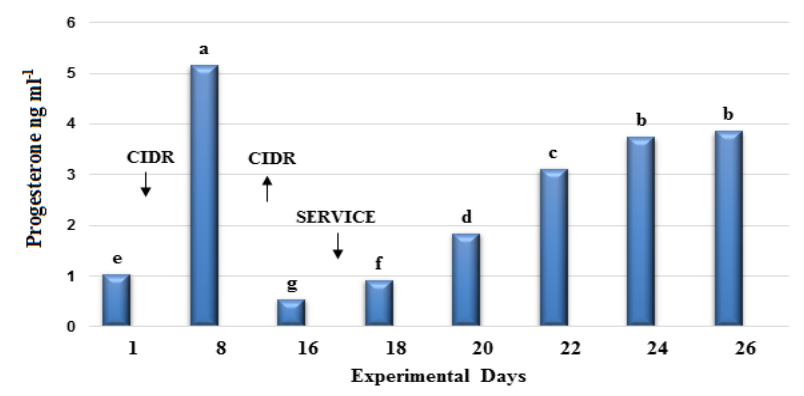

Figure 4. Concentration of progesterone in ewes during estrus synchronization with progestogen and beginning of pregnancy. CIDR: vaginal progesterone-releasing device; PGF $2 \alpha$ : F2 $\alpha$-prostaglandin. Different letters (a, b, c, d, e, $\mathrm{f}, \mathrm{g})$ indicate statistically significant differences between bars $(\mathrm{p}<0.05)$.

Glucose and insulin concentration in blood serum

Inclusion of 5 and $10 \%$ coffee pulp in the diet did not modify $(p>0.05)$ the content of glucose and insulin. A higher concentration of glucose and insulin $(\mathrm{p}<0.05)$ was observed in all treatments in the last two samples, which was the period when animals were supplemented with coffee pulp (Table 5).

Table 5. Concentration of glucose and insulin in ewes supplemented with coffee pulp during estrus synchronization.

\begin{tabular}{lcccc}
\hline Sampling & Glucose & SEM & Insulin & SEM \\
& $\left(\mathbf{m g} / \mathbf{d l}^{-\mathbf{1}}\right)$ & & $\left(\mathbf{n g ~ m l ^ { - 1 }}\right)$ & \\
\hline 1 & $62.60^{\mathrm{b}}$ & 0.014 & $0.39^{\mathrm{b}}$ & 0.019 \\
2 & $65.40^{\mathrm{a}}$ & 0.014 & $0.51^{\mathrm{a}}$ & 0.019 \\
3 & $65.26^{\mathrm{a}}$ & 0.014 & $0.49^{\mathrm{a}}$ & 0.019 \\
\hline
\end{tabular}

Different superscript letters $\left({ }^{a}, b, c\right)$ within the same column indicate statistically significant differences $(\mathrm{p}<0.05)$. SEM: standard error of the mean.

\section{Discussion}

The antioxidant compounds present in coffee pulp (Arellano et al., 2011; Murthy and Naidu, 2012) increase antioxidant capacity. Oat hay was used as a source of forage, and the 5\% replacement for coffee pulp slightly increased antioxidant capacity; however, the inclusion of $10 \%$ increased more than three times the antioxidant capacity, so we suggest that inclusion of pulp is feasible for diets with low amounts of antioxidants, since little of this by-product is needed to improve the antioxidant capacity of the diet.

\section{Reproductive performance}

Inclusion of pulp for a short period prior to breeding did not affect the reproductive variables. In a previous study (Salinas-Rios et al., 2016), we found that supplementing with $450 \mathrm{~g}$ of concentrate with $25 \%$ of coffee pulp (corresponding to a coffee pulp consumption of 112.5 g per day) for 25 days before and 25 days after CIDR withdrawal resulted in decreased gestation percentage, which was attributed to the caffeine present in coffee pulp. If ewes consumed $1.5 \mathrm{~kg}$ feed, then pulp consumption was $75 \mathrm{~g}$ for the treatment with $5 \%$ inclusion, 
and $150 \mathrm{~g}$ for the treatment with $10 \%$. On average, $5 \%$ inclusion corresponds to a lower level, and $10 \%$ at a higher level than previously offered (Salinas-Rios et al., 2016); therefore, we assume that up to $10 \%$ pulp supplementation for a short period is feasible, although the maximum inclusion should be evaluated.

Adverse effects of coffee pulp on reproduction have been reported to disappear when supplementation is suspended. Salinas-Rios et al. (2016) did not observe more reduction in gestation rate after finishing supplementation. In the present study, reproductive variables were not affected when supplementation was provided during estrus synchronization. In this regard, Natarajan et al. (2007) indicated that caffeine half-life is 103 hours in plasma.

Caffeine was previously reported as not reducing fertility in women (Wesselink et al., 2016); According to Valenzuela (2010), pregnant women consuming less than 300 mg of caffeine do not present risks. A study with pregnant women in which one group was given decaffeinated and the other caffeinated coffee concluded that caffeine intake reduction starting in mid-gestation had no effect on the duration of pregnancy or birth weight (Molina, 2007). According to these data, the damage that caffeine could cause depends on the dose consumed. Coffee pulp contains $0.57 \%$ caffeine (Salinas et al., 2014), so consumption of $150 \mathrm{~g}$ of coffee pulp in the treatment with $10 \%$

supplementation would be equivalent to a consumption of $0.855 \mathrm{~g}$ caffeine, although part of this caffeine could be degraded in the rumen.

\section{Oxidative state}

The antioxidant capacity in blood plasma was greater when coffee pulp increased; whereas malondialdehyde concentration followed an inverse tendency, indicating that antioxidants in coffee pulp help reduce lipid peroxidation. Gupta et al. (2007) reported an increase in MDA, and therefore oxidative stress, causing placental dysfunction and the repercussions originated by this disorder, such as recurrent pregnancy loss, defective embryogenesis, among other problems; thus, during this disorder there is high antioxidant demand and antioxidant capacity decreases (Kankofer et al., 2010). Recent studies have shown the ability of some plants to counteract lipid oxidation; Pérez-Hernández et al. (2013) added cranberry extract (Vaccinium meridionale SW) to $50 \mathrm{~g}$ corn oil observing that lipid oxidation decreased; likewise, Londoño et al. (2013) evaluated the antioxidant activity of different types of coffee by checking their ability to prevent low density lipoprotein (LDL) oxidation. Furthermore, Zhang et al. (2011) found that adding antioxidants to hen diets increases the incubation ability of fertile eggs, increasing the number of hatchings. Benefits of improving the oxidative status in animals have been reported; for example, Sönmez et al. (2009) found that vitamin $\mathrm{E}$ prevents overproduction of free radicals, thereby preventing oxidation and increasing the number of multiple births. Placental retention is also reduced and improvement in the immune system has been observed (Spears and Weiss, 2008). In addition, improved antioxidant capacity in lambs has been reported by supplementing their mothers with antioxidants (Nieto et al., 2010); however, in the present study, reproductive benefits were not observed by improving the antioxidant status in ewes, probably due do the pregnancy rate in the control group being $90 \%$, which is high. However, benefits of coffee pulp during oxidative stress -when antioxidant requirement increases- should be evaluated.

\section{Progesterone}

Coffee pulp does not affect P4 concentration in primiparous ewes. The highest progesterone concentration was reached when the animals had the CIDR combined with the corpus luteum present at that moment in the ovary. Accordingly, supplementing coffee pulp for a short period prior to pregnancy would not have a negative effect on this hormone; progesterone is the main hormone 
responsible for maintaining pregnancy, and low concentrations at the beginning of gestation could trigger abortions (Diskin and Morris, 2008); its increase is, therefore, associated with improved gestation rate (Flores et al., 2013).

\section{Glucose and insulin}

Glucose and insulin concentrations were not affected by coffee pulp inclusion in the diet. Glucose concentration was $64.42 \mathrm{mg} / \mathrm{dl}$ during estrus synchronization. These results are similar to those reported by Balaro et al. (2015) who found an average concentration of $64.8 \mathrm{mg} / \mathrm{dl}$ in sheep under tropical conditions. The optimal glucose range is between 50 and $80 \mathrm{mg} / \mathrm{dl}$ (Kaneko, 1980), hence, all treatments in all samples were within normal range.

Insulin concentrations in this study ranged from 0.39 to $0.51 \mathrm{ng} / \mathrm{ml}$ between treatments during estrus synchronization. It has been reported that concentrate supplementation increases insulin and glucose concentrations (Razz and Clavero, 2004; Noro et al., 2006; Catunda et al., 2013). This agrees with our results; although coffee pulp did not modify glucose and insulin concentrations in ewes, they increased when animals consumed the concentrate. In our previous study (Salinas et al., 2015) we found that feeding coffee pulp to sheep during fattening reduces fat in the rumen and intestines which is not desirable in pregnant sheep, since, during this time the female accumulates fat for lactation. This fat mobilization could affect the metabolic state of the animal. In this regard, Mahmoud and Azab (2014) reported that glucose and insulin concentrations vary throughout pregnancy and lactation in goats, so it is assumed to be a normal mechanism for the development of the embryo and fetus, and the physiological processes occurring during those stages. Caffeine intake can alter glucose metabolism (Du et al., 2006), so coffee may contain compounds that increase glucose absorption and decrease insulin. Bilge et al. (2017) gave instant coffee to people and measured metabolic hormones in blood three hours post consumption finding no change in glucose or insulin concentration. Van Dam et al. (2004) reported that glucose metabolism could be modified during coffee ingestion. Glucose and insulin concentrations may play a crucial role in pregnancy. During this period there is an increase in glucose levels, necessary for fetus survival, who obtains this metabolite from the mother (Herrera, 1997). This study found that coffee pulp at the dose and time supplied does not alter glucose or insulin levels.

Our results indicate that up to $10 \%$ coffee pulp can be included in the diet of ewes for 16 days prior to breeding with no detrimental effects on pregnancy, estrus or prolificacy, as well as progesterone, glucose or insulin concentrations. Additionally, coffee pulp improves the oxidative status of the animal, which merits further investigation about its potential benefits on the reproductive ability of sheep.

\section{Declarations}

\section{Conflicts of interest}

The authors declare they have no conflicts of interest with regard to the work presented in this report

\section{Author contributions}

All authors were responsible for the design, experimentation, analysis, writing and final approval of the work.

\section{References}

Arellano GM, Ramírez CA, Mancera TT, Pérez MG, Saucedo CG. Antioxidant activity of fermented and on-fermented coffee (Coffea arabica) pulp extracts. Food Technol Biotechnol 2011; 49:374-378.

Agarwal A, Gupta S, Sharma RK. Role of oxidative stress in female reproduction. Reprod Biol Endocrinol 2005; 14:3-28. https: 10.1186/14777827-3-28 
Balaro MF, Brandão FZ, Peneiras AB, Oba E, da Fonseca JF, Almosny NR, da Cruz Cardoso E. Reproductive performance, metabolic and hormonal profiles of Santa Inês ewes in winter and summer under tropical conditions. Trop Anim Health Prod 2015; 47(3):627-631. https: $10.1007 / \mathrm{s} 11250-015-0757-\mathrm{z}$

Benowitz NL. Clinical pharmacology of caffeine. Annu Rev Med 1990; 41(1):277-288. https: 10.1146/annurev.me.41.020190.001425

Benzie IF, Strain JJ. The ferric reducing ability of plasma (FRAP) as a measure of "antioxidant power": The FRAP assay. Anal Biochem 1996; 239:70-76. https: 10.1006/abio.1996.0292

Berchieri-Ronchi CB, Kim SW, Kim SW, Zhao Y, Correa CR, Yeum KJ, Ferreira AL. Oxidative stress status of highly prolific sows during gestation and lactation. Animal 2011; 5(11):1774-1779. https: $10.1017 /$ S1751731111000772.

Bilge U, nlüoğlu İ, Gültekin GS, Özgül MN, Şule YN, Bilgin M. The acute effect of coffee intake on hormones that affect glucose and glucose metabolism in healthy individuals. Biomed Res 2017; Special Issue: S531-S536.

Casamassima D, Palazzo M, Martemucci G, Vazzarri F, Corino C. Effects of verbascoside on plasma oxidative status and blood and milk production parameters during the peripartum period in Lacaune ewes. Small Rumin Res 2012; 105:1-8. https:10.1016/j.smallrumres.2011.12.001

Castillo C, Hernández J, Bravo A, LopezAlonso M, Pereria V, Benedito JL. Oxidative status during late pregnancy and early lactation in dairy cows. Vet J 2005; 169:286-292. https: $10.1016 /$ j.tvj1.2004.02.001

Catunda AGV, Lima ICS, Bandeira GC, Gadelha, Pereira ES, Salmito-Vanderley CSB, Araújo AA, GA Martins, Campos CAN. Blood leptin, insulin and glucose concentrations in hair sheep raised in a tropical climate. Small Rumin Res 2013; 114:272-279. https: 10.1016/j.smallrumres.2013.07.008
Daly JW. Mechanism of action of caffeine. Caffeine, Coffee, and Health, Raven Press, New York 1993; pp. $97-150$.

Diskin MG, Morris DG. Embryonic and early foetal losses in cattle and other ruminants. Reprod Domest Anim 2008; 43:260-267. https: $10.1111 / \mathrm{j} .1439-0531.2008 .01171 . x$.

Du Y, Melchert HU, Knopf H, Braemer-Hauth, Pabel E. Association of serum caffeine concentrations with serum glucose levels in caffeine-drug users and non-users - results of German National Health Surveys. Diabetes, Obes Metab 2006; 9:756-758. https: 10.1111/j.1463-1326.2006.00689.x

Echeverria MC, Nuti M. Valorisation of the residues of coffee agro-industry: perspectives and limitations. Open Waste Manag J 2017; 10:13-22. https: $10.2174 / 1876400201710010013$

Flores O, Velázquez R, López R, Benítez S, Oropeza A, Hernández C. Porcentaje de concepción en vacas lecheras tratadas con progesterona cinco días después de la inseminación. Rev Mex Cienc Pecu 2013; 4(4):507-514.

Fumihiro S, Hideto Y, Kana S, Yasuaki S, Emi H, Mamoru M. Caffeine intake, CYP1A2 polymorphism and the risk of recurrent pregnancy loss. Mol Hum Reprod 2005; 11:357-60. https: 10.1093/molehr/gah175

Guerin P, El Mouatassim S, Ménezo Y. Oxidative stress and protection against reactive oxygen species in the pre-implantation embryo and its surroundings. Hum Reprod Update 2001; 7(2):175-189. https: 10.1093/humupd/7.2.175

Gupta S, Agarwal A, Banerjee J, Alvarez J. The role of oxidative stress in spontaneous abortion and recurrent pregnancy loss: a systematic review. Obstet Gynecol Surv 2007; 62(5):335-347. https: 10.1097/01.ogx.0000261644.89300.df

Herrera E. Metabolismo lipídico durante la gestación. Alim Nut Salud 1997; 4(2):43-49.

Kaneko JJ. Clinial Biochemistry of Domestic Animals. Third edition; 1980. 
Kankofer M, Albera E, Feldman M, Gundling N, Hoedemaker M. Comparison of antioxidative/ oxidative profiles in blood plasma of cows with and without retained fetal placental membranes. Theriogenology 2010; 74:1385-1395. https: 10.1016/j.theriogenology.2010.06.009

Lima de Souza A, García R, Cabral LS, Albuquerque PM, Ferreira DV. Coffee hull in the diet of dairy heifers: nitrogen balance and microbial protein synthesis. Rev Bras Zootec 2010; 39(5):1141-1145. https: 10.1590/S1516-35982010000500027

Londoño L, Naranjo C, Quintero O, Mónica M. Estudio de los cambios de la actividad antioxidante en bebidas de café durante su periodo de vida útil usando métodos in-vitro y ex- vivo. Vitae 2013; 20(2):95-104.

Mahmoud S, Azab M. Regulation of glucose level durng late pregnancy and onset of lactation in Egyptian female Baladi goats. Small Rumin Res 2014; 121:320-324. https: 10.1016/j.smallrumres.2014.06.0091

Molina SFP, I Alapont VM. Restringir la ingesta de cafeína en embarazadas a partir de las 20 semanas de embarazo no tiene impacto en el peso de nacimiento del neonato ni en la duración de la gestación. Evid Pediatr 2007; 3(2):45. https: vol3/2007 numero_2/2007_vol3_numero2.16.htm

Murthy PS, Naidu MM. Recovery of Phenolic Antioxidants and functional compounds from coffee industry By-Products. Food Bioproc Tech 2012; 5:897-903. https: 10.1007/s11947-010-0363-Z

Natarajan G, Lulic-Botica M, Aranda JV. Pharmacology Review: Clinical Pharmacology of caffeine in the newborn. Neo Rev 2007; 5:214-221. https: 10.1542/neo.8-5-e214

Nawrot P, Jordan S, Eastwood J. Effects of caffeine on human health. Food Addit Contam 2003; 20:130. https: 10.1080/0265203021000007840

Nieto G, Díaz P, Bañon S, Garrido MD. Dietary administration of ewe diets with a distillate from rosemary leaves (Rosmarinus officinalis L.):
Influence on lamb meat quality. Meat Sci 2010; 84:23-29. https: 10.1016/j.meatsci.2009.08.001

Noro M, Vargas V, Pulido RG, Wittwer F. Efecto del tipo de concentrado sobre indicadores sanguíneos del metabolismo de energía y de proteínas en vacas lecheras en pastoreo primaveral. Arch Med Vet 2006; 38(3):227-232. https: org/10.4067/S0301$732 \times 2006000300005$

NRC. Nutrient Requirements of Sheep, Sixth Revised. Washington, D.C; 1985.

Ohkawa H, Ohishi N, Yagi K. Assay for lipid peroxides in animal tissues by thiobarbituric acid reaction. Anal Biochem 1979; 95:351-358. https: 10.1016/0003-2697(79)90738-3

Pedraza-Beltrán P, Estrada-Flores JG, MartínezCampos AR, Estrada-López I, Rayas-Amor AA, Yong-Angel G, Figueroa-Medina M, Avilés Nova $\mathrm{F}$, Castelán-Ortega OA. On-farm evaluation of the effect of coffee pulp supplementation on milk yield and dry matter intake of dairy cows grazing tropical grasses in central Mexico. Trop Anim Health Prod 2012; 44(2):329-336. https: 10.1007/s11250-011-0025-9

Pérez-Hernández L, Chávez-Quiroz K, MedinaJuárez L, Gámez-Meza N. Compuestos fenólicos, melanoidinas y actividad antioxidante de café verde y procesado de las especies Coffea arabica y Coffea canephora. Biotecnia 2013; 15(1):51-56. https: 10.18633/bt.v15i1.136

Razz R, Clavero T. Niveles de urea, fósforo, glucosa e insulina de vacas en ordeño suplementadas con concentrado en un sistema de Panicum maximum y Leucaena leucocephala. REV CIENT-FAC CIEN V 2004; 14(4):365-369.

Restrepo-Sánchez DC, Narváez-Cuenca CE, Restrepo-Sánchez LP. Extracción de compuestos con actividad antioxidante de frutos de guayaba cultivada en Vélez-Santander, Colombia. Quím Nova 2009; 32:1517-1522. https: 10.1590/S010040422009000600030 
SAGARPA, Secretaría de Agricultura, Ganadería, Desarrollo Rural, Pesca y Alimentación. Norma Oficial Mexicana NOM-062-ZOO-1999, especificaciones técnicas para la producción, cuidado y uso de los animales de laboratorio. Diario Oficial de la Federación 2001. 75:113-160.

Salinas-Rios T, Ortega-Cerrilla ME, SánchezTorres-Esqueda MT, Hernández-Bautista J, DíazCruz A, Figueroa-Velasco JL, Guinzberg-Perrusquía R, Cordero-Mora JL. Productive performance and oxidative status of sheep fed diets with coffee pulp. Small Rum Res 2015; 123(1):17-21.

https: 10.1016/j.smallrumres.2014.09.008

Salinas-Rios T, Sánchez-Torres-Esqueda MT, DíazCruz A, Cordero-Mora JL, León MC, HernándezBautista J, Aquino RN. Oxidative status and fertility of ewes supplemented coffee pulp during estrous synchronization and early pregnancy. Rev Colomb Cienc Pec 2016; 29(4):255-263. https: $10.17533 /$ udea.rccp.v29n4a02

Salinas-Rios T, Sánchez-Torres-Esqueda MT, Ortega-Cerilla ME, Soto-Hernández M, DíazCruz A, Hernández-Bautista J, Nava-Cuellar C, Vaquera-Huerta H. Changes in composition, antioxidant content, and antioxidant capacity of coffee pulp during the ensiling process. Rev Bras Zootec 2014; 43(9):492-498. https: 10.1590/S151635982014000900006

SAS $^{\circledR}$, Statistical Analisys System. SAS/STAT User's Guide. Proceeding Versión 9. SAS Institute Incorporation. Cary, NC, USA; 2002.
SönmezM, BozkurtT, Türk G, Gür S, Kizil M, YüceA. The effect of vitamin $E$ treatment during preovulatory period on reproductive performance of goats following estrous synchronization using intravaginal sponges. Anim Reprod Sci 2009; 114:183-192. https: 10.1016/j.anireprosci.2008.09.007

Spears JW, Weiss WP. Role of antioxidants and trace elements in healt and immunity of transition dairy cows. Vet J 2008; 176:70-76. 10.1016/j.tvj1.2007.12.015

Valenzuela A. El café y sus efectos en la salud cardiovascular y en la salud materna. Rev Chil Nutr 2010; 37(4):514-523. https: 10.4067/S071775182010000400013

Van Dam RM, Pasman WJ, Verhoef P. 2004. Effects of Coffee Consumption on Fasting Blood Glucose and Insulin Concentrations: randomized controlled trials in healthy volunteers. Diabetes Care 2004; 27(12):2990-2992. https: 10.2337/ diacare.27.12.2990

Wesselink AK, Wise LA, Rothman KJ, Hahn KA, Mikkelsen EM, Mahalingaiah y Hatch EE. Caffeine and caffeinated beverage consumption and fecundability in apreconception cohort. Reprod Toxicol 2016; 62:39-45. https: 10.1016/j. reprotox.2016.04.022

Zhang W, Zhang KY, Ding XM, Bai SP, Hernandez JM, Yao B, Zhu Q. Influence of canthaxanthin on broiler breeder reproduction, chick quality, and performance. Poult Sci 2011; 90(7):1516-1522. https: $10.3382 /$ ps.2010-01126 